\title{
Oral Supplementation of L-Arginine in Patients with Severe Chronic Obstructive Pulmonary Disease (COPD)
}

\author{
Tayyem $^{1}$, R. F., H. R., Takruri ${ }^{2}$, and N. A. Shroof ${ }^{3}$ \\ ${ }^{1}$ Faculty of Allied Health Sciences, The Hashemite University, Jordan, \\ rtayyem@hu.edu.jo, ${ }^{2}$ Faculty of Agriculture, Jordan University, Jordan ${ }^{3}$ Faculty \\ of Medicine, Jordan University, Jordan
}

\begin{abstract}
The study was conduct to evaluate the effect of oral L-arginine supplementation on exercise tolerance in patients with severe COPD. Patients $(n=35)$ with specific conditions were selected and divided randomly into three groups. Group A was the placebo group $(n=11)$, group B was supplemented with $15 \mathrm{~g} \mathrm{~L}$-arginine/day $(\mathrm{n}=12)$, and group $\mathrm{C}$ consumed $25 \mathrm{~g} \mathrm{~L}$ arginine/day $(n=12)$. The study period was 14 days. Many parameters were measured at the beginning (day 0), during (day 7), and at the end of the study (day 14). These parameters included: plasma and urinary concentrations of L-arginine, L-citrulline, and L-ornithine; serum and urinary urea and creatinine; urinary nitrate and nitrite; forced expiratory volume at one second $\left(\mathrm{FEV}_{1}\right)$; arterial blood gases (ABG's); the degree of pulmonary hypertension (PHT); and exercise tolerance six minute walk (6MW). The results showed that there was a statistically significant $(\mathrm{p}<0.05)$ increase in serum and urinary urea in both groups B and C particularly after 7 days from starting the supplementation. Also, there was a statistically significant $(\mathrm{p}<0.05)$ increase in both plasma L-arginine and L-ornithine concentrations during the supplementation period. Plasma L-citrulline level and urinary nitrate level indicated no specific changes as a response for L-arginine supplementation. There was a trend of increase (but insignificant) in arterial oxygen partial pressure $\left(\mathrm{P}_{\mathrm{a}} \mathrm{O}_{2}\right)$ and oxygen saturation percent $\left(\mathrm{O}_{2}\right.$ sat\%) in groups $\mathrm{B}$ and C. This tendency of increase was more in group B. In spite of the slight increase in oxygenation, in patients with severe COPD, oral L-arginine supplementation did not cause any improvement in exercise tolerance.
\end{abstract}

Key words: Arginine oral supplementation, chronic obstructive pulmonary disease (COPD), exercise tolerance, arterial blood gas.

$$
\begin{aligned}
& \text { أثر تتوبد الحصن الأميف أرجنين عنطرق الفم عل تحطل المجهود } \\
& \text { لمرضف النداد الرئة الشنيد المزمن المبحن } \\
& \text { رب مافلي ز تيّيّ م'،حاه } 2 \text { الت كروري"، ، نلي فسعليملن اللشروف") }
\end{aligned}
$$

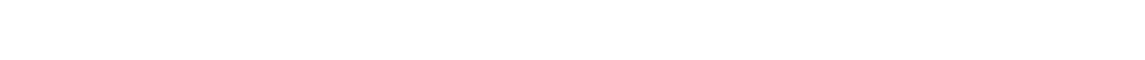

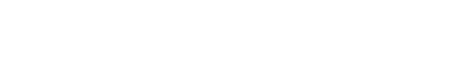




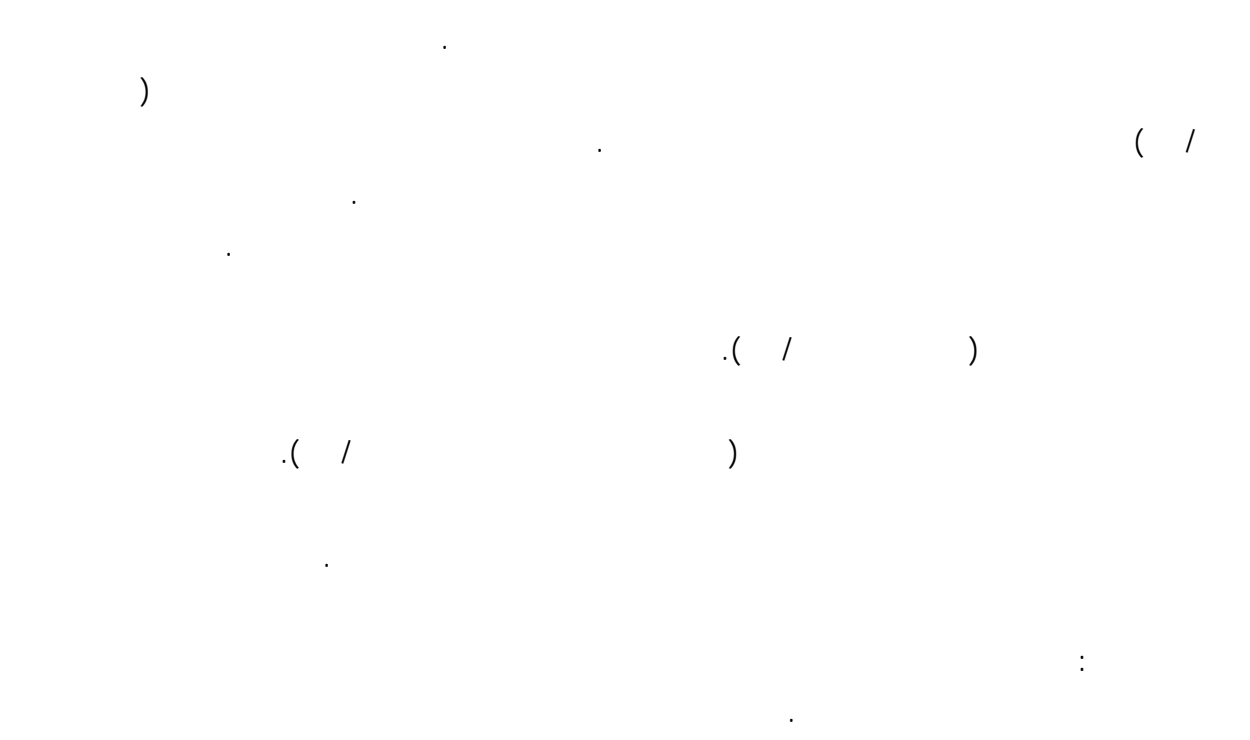

\section{Introduction}

Chronic obstructive pulmonary disease (COPD) is a disease characterized by obstructive airways, on expiration rather than on inspiration, that may lead to death due to respiratory or cardiorespiratory failure (Allegra and Blasi, 1999). In European Union countries; COPD and asthma as well as pneumonia are the third most common cause of death (Siafakas et al., 1995). In North America, COPD is the fourth leading cause of death, with increasing prevalence and mortality rate (U.S. statistics on COPD, 1997).

Obstruction in airways and damage in alveoli may cause disruption in $\mathrm{O}_{2}$ diffusion. This disruption in the $\mathrm{O}_{2}$ diffusion may cause depression in $\mathrm{PaO}_{2}$ (arterial partial pressure of oxygen) and elevation in $\mathrm{PaCO}_{2}$ (arterial partial pressure of carbon dioxide) (Allegra and Blasi, 1999; Miller, 1983; Winshaw and Murray, 1980). Hypoxia that results from prolonged $\mathrm{PaO}_{2}$ depression may cause pulmonary endothelium-dysfunction (Loscalzo, 1992; Dinh-xuan et al., 1991). Aggravation of these circumstances may lead to pulmonary vasoconstriction and consequent gradual elevation in pulmonary artery blood pressure leading to pulmonary hypertension (PHT) (Rounds and Hills, 1984). All these consequences are manifested as severe dyspnea and exercise intolerance to an extent that the patient is unable to perform any light activity and becomes dyspnic even at rest (Allegra and Blasi, 1999; Bauerle, 1998; Miller, 1983).

Nitric oxide (NO) inhalation has been recently used due to its significant vasodilatory effect. This effect could be accomplished by replacing a relative reduction of endogenous production (Shirai et al., 1996; Lowenstein et al, 1994; Roberts et al., 1992; Pepke-Zaba et al., 1991). Nonetheless, although the impressive shortterm effects of inhaled NO are accepted, its use is not without problems. Some patients fail to respond (Goldman, 1996), and its efficacy with prolonged use in some conditions has been questioned (Kinsella, and Abman, 1998). In addition, inhaling high amounts of NO may cause methemoglobinemia, asphyxia, and death (Roberts et al., 1992). However, these complications can be avoided if NO produced endogenously in a rate sufficient is to the body requirements.

In vivo and in vitro experiments illustrated that L-arginine is the precursor for NO produced by the action of the enzyme nitric oxide synthase (NOS) (Mehta et al., 1996; Palmer, 1988). In Keeping with this, L-arginine supplementation was found to exert a beneficial effect on the integrity of vascular endothelial-cell function especially in cases of vasoconstriction (Mitani, 1997; Gold et al., 1990). This effect can be attributed to nitric oxide production during the metabolism of L-arginine (Wascher et al., 1997; Loscalzo, 1995; Moncada and 
Higgs, 1993; Palmer et al, 1988). Moreover, Eddahibi et al., (1992) showed that administration of excess L-arginine may restore endothelium-dependent vasodilatory responses in hypoxia-induced PHT in rabbits. Additionally it may protect against the development of PHT if administrated before exposure to hypoxia.

Therefore, the present study was proposed to investigate the effect of Larginine oral supplementation on exercise tolerance in patients with severe COPD. This study was designed to include three groups of severe COPD patients: two of them would receive two different doses of L-arginine (15 or $25 \mathrm{~g} /$ day for 14 days) orally and the third one would be a control group.

\section{Materials and Methods}

Eligibility:

Male patients who were chosen to be included in the study had severe chronic obstructive pulmonary diseases (COPD) with specific characteristics:

Patients were excluded if they had coronary heart diseases, IDDM, renal failure, liver impairment, gastrointestinal diseases, intestinal resection or any malignant tumor.

\section{Study Protocol:}

42 male out-patients (free-living) aged 48-75-years (Mean \pm S.D.: 66 \pm 8 ) with normal body mass index (BMI) (23.7 \pm 5.5$)$ were divided into 3 groups. Six of those patients withdrew from the study at different times due to transportation difficulties, inability to continue taking L-arginine for 14 days and the pain which results from withdrawing blood for arterial blood gases measurements. One patient from the placebo group died during the study period. Therefore, the number of patients was reduced to 35; group A was the placebo group $(n=11)$, group $B$ was supplemented with $15 \mathrm{~g}$ L-arginine/day $(\mathrm{n}=12)$, and group $\mathrm{C}$ consumed $25 \mathrm{~g} \mathrm{L-}$ arginine/day $(\mathrm{n}=12)$. The L-Arginine preparation was given to the patients for 14 days. The L-arginine was prepared as powder filled in paper sachets. The patients were instructed to dissolve the content of the sachets in $50 \mathrm{ml}$ of water and drink it within 5 minutes. COPD maintenance medication (such as, bronchodilator, inhaled corticosteroids and frequent nebulizer) was kept constant throughout the study in all groups.

Measurements of Arterial blood gases (ABG's) were performed at the beginning (day 0), after one week (day 7), and after two weeks (day 14) of starting administration of L-arginine, whereas lung function and echocardiograph were measured at the beginning and after two weeks of starting the supplementation. Exercise tolerance was performed at days 0 and 14 by measuring the change in oxygen saturation and heart rate during the walking period.

The study was conducted in Jordan University Hospital and King Hussein Medical Center in Amman at clinics of respiratory diseases. The University Ethics Committee approved the study protocol and written consents were obtained from all patients.

Preparation of L-Arginine Sachets ${ }^{1}$ :

L-arginine was purchased as whiteodorless crystalline powder from Ajinomoto Co. (Tokyo, Japan). L-arginine sachets were prepared by adding lemon flavor, color, citric acid and sugar and artificial sweetener. The sachets were prepared so that each sachet contained $5 \mathrm{~g}$ L-arginine and some excipients. The placebo sachets contained only excipients. These contents were mixed thoroughly and sieved by 250-mesh sieve. Sachets were filled and stored at room temperature under dark conditions.

\footnotetext{
1 Preparation of all sachets were carried out in Research and Development Department, United Pharmaceuticals Manufacture (UPM), Amman.
} 


\section{Biochemical Measurements}

Urea and Creatinine Analyses ${ }^{2}$ :

- Serum urea and creatinine: Fasting venous blood samples were collected before the initiation of each treatment and after the first and second week. The serum was analyzed for urea and creatinine using an automated analyzer (COBAS Integra 700, Roche, Switzerland), on the same day of collection.

- Urine samples were collected for 24hours to measure total volume. Urea and creatinine of urine samples were determined using the same automated analyzer used for blood samples.

Amino Acid Analysis ${ }^{3}$ :

Amino acid analysis of plasma and urine samples were performed to detect the level of L-arginine, L-citrulline, and Lornithine. The gradient HPLC system was used. The analysis was conducted under specific conditions described by Teerlink et al., (1994). Blood samples were collected in sodium heparin tubes (Vacutainer, France). Urine samples were taken from 24-hour urine collection.

The samples were derivatized by $\mathrm{O}$ pthaldialdehyde (OPA) (Acros Organics, New Jersey, USA), and 3mercaptopropionic acid (MPA) (Acros Organics, New Jersey, USA).

Standards preparation: $2.5 \mu \mathrm{mole} / \mathrm{ml}$ stock standard of different amino acids (Larginine, L-ornithine, L-citrulline) were used. Different dilutions ranging from 3.25 $12.5 \mu \mathrm{mole} / \mathrm{dl}$ were used to establish a standard calibration curve.

2 The analysis of serum and urine of urea and creatinine was done in the Biochemical Laboratory, Jordan University Hospital and King Hussein Medical Center, Amman

3 Analysis of serum and urine amino acids were conducted in Research and Development Department, United Pharmaceuticals Manufacture (UPM), Amman
Chromatography conditions: The analyses of amino acids were performed using a Merck-Hitachi HPLC interface model-7200 (Tokyo, Japan). The analysis was carried under specific conditions and according to Teerlink et al., (1994).

Urinary Nitrate and Nitrite ${ }^{4}$ :

Urinary nitrite and nitrate were measured using a capillary ion analyzer (CIA), (Waters CIA, MA, USA). This measurement was carried out to detect the formation of NO in the body.

Lung Function Test ${ }^{5}$ :

Forced expiratory volume at one second $\left(\mathrm{FEV}_{1}\right)$ was measured by spirometry $\left(V_{M A X} 2\right.$, New York, USA). The spirometry was calibrated daily and the standard $\mathrm{FEV}_{1}$ value was not be less than $98 \%$ of reference volume. $\mathrm{FEV}_{1}$ is an indicator for the improvement for the overall condition of the patients.

Arterial Blood Gases ${ }^{6}$ :

Arterial blood gas analyzer (AVL-993, Graz, Austria) was used to measure arterial oxygen partial pressure $\left(\mathrm{P}_{\mathrm{a}} \mathrm{O}_{2}\right)$, arterial carbon dioxide partial pressure $\left(\mathrm{P}_{\mathrm{a}} \mathrm{CO}_{2}\right), \mathrm{O}_{2}$ saturation percent and $\mathrm{pH}$. The analyzer was automatically calibrated every 4 hours and standards of known values were injected daily to check its accuracy. Any improvement in $\mathrm{P}_{\mathrm{a}} \mathrm{O}_{2}$ and $\mathrm{P}_{\mathrm{a}} \mathrm{CO}_{2}$ could be considred as an indicator for the vasodilatory effect of arginine.

\footnotetext{
${ }^{4}$ The analysis of nitrate and nitrite was performed at Water and Environment Research and Study Center, The University of Jordan, Amman

5 These parameters were determined in Jordan University Hospital and King Hussein Medical Center, Amman.
} 
Echocardiography ${ }^{7}$ :

The echocardiography was performed for the study patients to detect the degree of pulmonary hypertension, using Ehco Doppler (Hewlett Packard, CONOS-2500, New York, USA). The test was done and the report was written by the cardiologist.

Exercise Tolerance Test ${ }^{8}$ :

The exercise tolerance test was performed using a pulse-oximetry instrument (NONIN, New York, USA). The test started by taking readings for oxygen saturation percent $\left(\mathrm{O}_{2}\right.$ sat\%) and heart rate (HR) at rest, then after walking for 6 minutes. The patients were instructed to walk as they used to and to tell if they became exhausted, developed palpitation, or felt weak or dyspnic during the walking period.

\section{Statistical Analysis}

Statistical analysis of data was performed using SAS package (version 6.12, 1997). Data were presented as Means \pm SE. Significance between groups and days were assessed by analysis of variance (ANOVA) using repeated measures ( $p<0.05$ ). The least significant difference (LSD) test was used to find significance differences between mean values for the following parameters: urea, creatinine, L-arginine, Lcitrulline, and L-ornithine, $\mathrm{P}_{\mathrm{a}} \mathrm{O}_{2}, \mathrm{P}_{\mathrm{a}} \mathrm{CO}_{2}, \mathrm{pH}$, FEV1, and exercise tolerance measurements (Heath, 1995).

6, 7, 8 These parameters were determined in Jordan University Hospital and King Hussein Medical Center, Amman.

\section{Results}

\section{Biochemical Results:}

\section{Serum Urea and Creatinine:}

Table 1 presents serum concentrations of urea and creatinine in the different groups during the study period. It is clear that Larginine supplementation caused significant area differences when the two groups which were supplemented with L-arginine are compared with placebo group at $7^{\text {th }}$ and $14^{\text {th }}$ days. The results of creatinine in the placebo group and in both groups that were supplemented with L-arginine and show no changes throughout the study period.

Urinary Urea and Creatinine Measurements:

Table 2 shows the urinary concentrations of urea and creatinine in the different groups during the study period. A significant difference appears between urinary urea results of the placebo and the group which received $15 \mathrm{~g}$ /day of L-arginine with the other group which consumed 25 g/day of L-arginine, on day 7. On the other hand, on the day 14 there is a significant increase in both groups $\mathrm{B}$ and $\mathrm{C}$ as compared with group A. Also, comparing urea values on day 0 and urea values on day 14 within the group supplemented with 15 $\mathrm{g}$ /day reveals significant differences whereas the significancy appears in the group received $25 \mathrm{~g}$ of L-arginine/day at the seventh day of supplementation.

Regarding the urinary creatinine values there were no significant differences among the three groups. 
Table 1. Serum concentrations of urea and creatinine in the different groups during the study period.

\begin{tabular}{lcccc}
\hline \multicolumn{1}{c}{ Parameter } & Days & $\begin{array}{c}\text { Group A }^{\#} \\
(\text { Mean } \pm \text { SE) }\end{array}$ & $\begin{array}{c}\text { Group B }^{\#} \\
(\text { Mean } \pm \text { SE) }\end{array}$ & $\begin{array}{c}\text { Group C }^{\#} \\
\text { Mean } \pm \text { SE) }^{\text {a }}\end{array}$ \\
\hline Urea & 0 & $5.5 \pm 1.4^{\text {a }}$ & $5.9 \pm 2.7^{\text {a } 1}$ & $6.2 \pm 4.2^{\text {a } 1}$ \\
$($ mmole/l) & 7 & $4.8 \pm 1.8^{\text {a } 1}$ & $8.0 \pm 1.7^{\text {a } 2}$ & $9.8 \pm 4.0^{\text {a } 2}$ \\
& 14 & $5.2 \pm 1.4^{\text {a } 1}$ & $8.1 \pm 2.4^{\text {a } 2}$ & $7.5 \pm 2.7^{\text {a } 1,2}$ \\
Creatinine & 0 & $96.2 \pm 22.2^{\text {a } 1}$ & $94.6 \pm 27.3^{\text {a } 1}$ & $83.0 \pm 12.4^{\text {a } 1}$ \\
$(\mu$ mole/l) & 7 & $81.4 \pm 12.9^{\text {a } 1}$ & $83.2 \pm 17.9^{\text {a } 1}$ & $86.5 \pm 20.8^{\text {a } 1}$ \\
& 14 & $86.7 \pm 14.7^{\text {a } 1}$ & $81.9 \pm 18.1^{\text {a } 1}$ & $84.2 \pm 20.2^{\text {a } 1}$ \\
\hline
\end{tabular}

\# Group A is placebo, group B includes the patients who received $15 \mathrm{~g}$ of L-arginine/day, whereas group $\mathrm{C}$ represents patients who received $25 \mathrm{~g}$ of L-arginine/day.

Different numbers indicate significant difference $(p<0.05)$ between values measured in different groups within the same day.

Table 2. Urinary output of urea and creatinine in the different groups during the study period.

\begin{tabular}{|c|c|c|c|c|}
\hline Parameter & Days & $\begin{array}{c}\text { Group A }^{\#} \\
(\mathrm{mmole} / 24 \mathrm{hr}) \\
(\text { Mean } \pm \text { SE })\end{array}$ & $\begin{array}{c}\text { Group B } \\
(\text { mmole/24 hr) } \\
(\text { Mean } \pm \text { SE })\end{array}$ & $\begin{array}{c}\text { Group C } \\
\text { (mmole/24 hr) } \\
(\text { Mean } \pm \text { SE) }\end{array}$ \\
\hline \multirow[t]{3}{*}{ Urea } & 0 & $310.3 \pm 184.2^{\text {a } 1}$ & $328.4 \pm 191.5^{\text {a } 1}$ & $311.7 \pm 191.3^{\text {a } 1}$ \\
\hline & 7 & $324.1 \pm 153.6^{\text {a } 1}$ & $369.9 \pm 140.2^{\text {a } 1}$ & $529.4 \pm 256.1^{\text {b } 2}$ \\
\hline & 14 & $298.7 \pm 141.2^{\text {a } 1}$ & $474.9 \pm 190.4^{\text {b } 2}$ & $492.3 \pm 144.1^{\mathrm{b} 2}$ \\
\hline \multirow[t]{3}{*}{ Creatinine } & 0 & $7.8 \pm 5.3^{\text {a } 1}$ & $8.8 \pm 3.2^{\mathrm{a} 1}$ & $9.5 \pm 6.3^{\text {a } 1}$ \\
\hline & 7 & $8.8 \pm 4.7^{\text {a } 1}$ & $7.1 \pm 2.5^{\text {a } 1}$ & $7.5 \pm 2.7^{\text {a } 1}$ \\
\hline & 14 & $7.1 \pm 4.0^{\text {a } 1}$ & $7.4 \pm 3.2^{\text {a } 1}$ & $6.7 \pm 3.5^{\text {a } 1}$ \\
\hline
\end{tabular}

\# Group A is placebo, group B includes the patients who received $15 \mathrm{~g}$ of L-arginine/day, whereas group $\mathrm{C}$ represents patients who received $25 \mathrm{~g}$ of L-arginine/day.

Different letters indicate significant difference $(\mathrm{p}<0.05)$ between values measured in different days within the same group.

Different numbers indicate significant difference $(\mathrm{p}<0.05)$ between values measured in different groups within the same day.

Plasma Concentrations of L-Arginine, LCitrulline and L-Ornithine:

The results of these three amino acids are shown in Table 3. It is clear that Larginine supplementation significantly increased plasma L-arginine levels in both groups that ingested 15 and $25 \mathrm{~g}$ of Larginine/day as compared with the placebo group and as compared with day 0 . However, there was no significant difference between the two experimental groups (receiving 15 and 25 g L-arginine/day). As for the results of citrulline, no changes were indicated in its level during the study period despite of continuous supplementation of Larginine for 14 days with different doses. The results of ornithine show an increase in ornithine plasma levels in response to length of supplementation (days) as well as doses. However, the results of plasma L-arginine and L-ornithine in the two groups which were supplemented with L-arginine show no significant changes when the comparison is between groups B and C on days 7 and 14 . 
Emir. J. Agric. Sci. 2003. 15 (2): 29-41

http://www.cfs.uaeu.ac.ae/research/ejas.html

Table 3. Plasma concentrations* of L-arginine, L-citrulline, and L-ornithine in the different groups during the study period.

\begin{tabular}{|c|c|c|c|c|}
\hline Amino Acid & Days & $\begin{array}{c}\text { Group A }^{\#} \\
(\mu \text { mole/l }) \\
(\text { Mean } \pm S E) \\
\end{array}$ & $\begin{array}{c}\text { Group B }^{\#} \\
(\mu \text { mole/l }) \\
(\text { Mean } \pm S E) \\
\end{array}$ & $\begin{array}{c}\text { Group C }^{\#} \\
(\mu \text { mole/l }) \\
(\text { Mean } \pm S E) \\
\end{array}$ \\
\hline \multirow[t]{3}{*}{ L-Arginine } & 0 & $75.13 \pm 24.92^{\text {a } 1}$ & $77.86 \pm 39.57^{\text {a } 1}$ & $80.91 \pm 29.97^{\text {a } 1}$ \\
\hline & 7 & $70.58 \pm 20.59^{\text {a } 1}$ & $118.87 \pm 55.42^{\text {b } 2}$ & $139.96 \pm 54.86^{\text {b } 2}$ \\
\hline & 14 & $97.73 \pm 34.83^{\text {a } 1}$ & $136.1 \pm 53.97^{\text {b } 2}$ & $128.55 \pm 47.23^{\text {b } 2}$ \\
\hline \multirow[t]{3}{*}{ L-Citrulline } & 0 & $36.04 \pm 15.52^{\text {a } 1}$ & $33.57 \pm 13.52^{\text {a } 1}$ & $34.18 \pm 16.77^{\text {a } 1}$ \\
\hline & 7 & $38.75 \pm 19.14^{\text {a } 1}$ & $40.04 \pm 12.51^{\mathrm{a} 1}$ & $38.41 \pm 11.99^{\text {a } 1}$ \\
\hline & 14 & $41.70 \pm 18.65^{\text {a } 1}$ & $40.72 \pm 12.64^{\text {a } 1}$ & $34.63 \pm 11.70^{\text {a } 1}$ \\
\hline \multirow[t]{3}{*}{ L-Ornithine } & 0 & $75.36 \pm 34.77^{\text {a } 1}$ & $111.99 \pm 66.06^{\mathrm{a} 1}$ & $85.58 \pm 36.44^{\text {a } 1}$ \\
\hline & 7 & $74.83 \pm 27.11^{\text {a } 1}$ & $236.47 \pm 112.95^{\mathrm{b} 2}$ & $269.18 \pm 135.13^{\text {b } 2}$ \\
\hline & 14 & $113.85 \pm 63.58^{\text {a } 1}$ & $249.66 \pm 114.35^{\text {b } 2}$ & $329.35 \pm 203.79^{\text {b } 2}$ \\
\hline
\end{tabular}

* The values of these amino acids are obtained by duplicate analysis with C.V. $<4 \%$.

\# Group A is placebo, group B includes the patients who received $15 \mathrm{~g}$ of L-arginine/day, whereas group $\mathrm{C}$ represents patients who received $25 \mathrm{~g}$ of L-arginine/day.

Different letters indicate significant difference $(\mathrm{p}<0.05)$ between values measured in different days within the same group.

Different numbers indicate significant difference $(\mathrm{p}<0.05)$ between values measured in different groups within the same day.

Urinary Output of Nitrate, L-Arginine, LCitrulline, and L-Ornithine:

The obtained findings for nitrate, larginine, l-citrulline, and l-ornithine show no significant difference among the three groups or between the baseline and after applying the treatment. The values of urinary L-arginine, L-citrulline, and Lornithine in the three groups were $41.3 \pm 16.31, \quad 31.1 \pm 7.5, \quad$ and $11.7 \pm 2.4$, respectively.

The value of urinary nitrate was $477.6 \pm 128.6$ for the three groups through the study. These results show no significant differences in nitrate concentrations among the three groups and within the same group. Nitrite was undetectable because it is easily and rapidly converted to nitrate.

Forced Expiratory Volume at One Second $\left(\mathrm{FEV}_{1}\right)$ :

The results demonstrate no significant changes in $\mathrm{FEV}_{1}$ among the three groups. Also, no significant differences could be seen among days 0,7 , and 14 within the same group. The change in $\mathrm{FEV}_{1}$ in group $\mathrm{A}$ was from $0.86 \pm 0.34$ (at the beginning of the study) to $0.9 \pm 0.28$ (at the end of the study) while in group $\mathrm{B}$ and $\mathrm{C}$ the change was from $0.85 \pm 0.14$ to $0.86 \pm 0.23$ and from $0.97 \pm 0.30$ to $1.01 \pm 0.37$, respectively. Arterial Blood Gases (ABG's)
Measurements:

The results of the arterial blood gases for patients of different groups during the study period are shown in Table 4. As it is apparent from the table, there is a trend of increment in $\mathrm{P}_{\mathrm{a}} \mathrm{O}_{2}$ in $\mathrm{B}$ and $\mathrm{C}$ groups. This increase, although not significant, appears to be more valuable in group $B$ than in group C. This improvement was associated with feelings of less dyspnea after the supplementation. Also, oxygen saturation $\left(\mathrm{O}_{2}\right.$ sat. \%) results show a trend of elevation comparable to that in $\mathrm{P}_{\mathrm{a}} \mathrm{O}_{2}$. However, $\mathrm{O}_{2}$ sat. $\%$ is usually calculated from the measurements of $\mathrm{P}_{\mathrm{a}} \mathrm{O}_{2}$. The data for $\mathrm{P}_{\mathrm{a}} \mathrm{CO}_{2}$, and $\mathrm{pH}$ show no significant changes. Nonetheless, there is a slight (but insignificant) tendency of decrease in $\mathrm{P}_{\mathrm{a}} \mathrm{CO}_{2}$ values when day 0 is compared with days 7 and 14 in the group supplemented with $25 \mathrm{~g}$ of L-arginine/day. 
Table 4. Arterial blood gases for patients of different groups during the study period.

\begin{tabular}{|c|c|c|c|c|}
\hline Parameter & Days & $\begin{array}{l}\text { Group A } \\
(\text { Mean } \pm S E)\end{array}$ & $\begin{array}{c}\text { Group B }^{\#} \\
(\text { Mean } \pm \text { SE })\end{array}$ & $\begin{array}{l}\text { Group C } \\
(\text { Mean } \pm \text { SE })\end{array}$ \\
\hline \multirow[t]{3}{*}{$\mathrm{P}_{\mathrm{a}} \mathrm{O}_{2}(\mathrm{mmHg})$} & 0 & $54.6 \pm 5.8^{\text {a } 1}$ & $52.6 \pm 10.1^{\mathrm{a} 1}$ & $53.81 \pm 10.3^{\text {a } 1}$ \\
\hline & 7 & $54.4 \pm 6.8^{\text {a } 1}$ & $57.9 \pm 10.4^{\text {a } 1}$ & $56.5 \pm 11.7^{\text {a } 1}$ \\
\hline & 14 & $56.1 \pm 4.1^{\text {a } 1}$ & $60.1 \pm 10.4^{\mathrm{a} 1}$ & $58.7 \pm 9.9^{\text {a } 1}$ \\
\hline \multirow[t]{3}{*}{$\mathrm{P}_{\mathrm{a}} \mathrm{CO}_{2}(\mathrm{mmHg})$} & 0 & $47.4 \pm 7.2^{\mathrm{a} 1}$ & $44.7 \pm 9.0^{\text {a } 1}$ & $46.4 \pm 11.2^{\text {a } 1}$ \\
\hline & 7 & $46.6 \pm 6.4^{\mathrm{a} 1}$ & $43.4 \pm 9.8^{\text {a } 1}$ & $44.4 \pm 9.1^{\mathrm{a} 1}$ \\
\hline & 14 & $48.4 \pm 5.8^{\text {a } 1}$ & $43.6 \pm 10.2^{\text {a } 1}$ & $43.7 \pm 7.5^{\text {a } 1}$ \\
\hline \multirow[t]{3}{*}{$\mathrm{O}_{2}$ Saturation (\%) } & 0 & $86.5 \pm 6.0^{\text {a } 1}$ & $86.3 \pm 7.2^{\text {a } 1}$ & $87.0 \pm 9.1^{\text {a } 1}$ \\
\hline & 7 & $86.9 \pm 5.7^{\text {a } 1}$ & $87.9 \pm 5.0^{\text {a } 1}$ & $88.5 \pm 6.0^{\text {a } 1}$ \\
\hline & 14 & $87.8 \pm 4.9^{\text {a } 1}$ & $88.9 \pm 5.9^{\text {a } 1}$ & $89.2 \pm 5.9^{\text {a } 1}$ \\
\hline \multirow[t]{3}{*}{$\mathrm{pH}$} & 0 & $7.39 \pm 0.04^{\mathrm{a} 1}$ & $7.40 \pm 0.03^{\text {a } 1}$ & $7.40 \pm 0.05^{\text {a } 1}$ \\
\hline & 7 & $7.42 \pm 0.05^{\text {a } 1}$ & $7.39 \pm 0.04^{\mathrm{a} 1}$ & $7.41 \pm 0.03^{\text {a } 1}$ \\
\hline & 14 & $7.40 \pm 0.06^{\text {a } 1}$ & $7.41 \pm 0.05^{\text {a } 1}$ & $7.41 \pm 0.02^{\text {a } 1}$ \\
\hline
\end{tabular}

\# Group A is placebo, group B includes the patients who received $15 \mathrm{~g}$ of L-arginine/day, whereas group $\mathrm{C}$ represents patients who received $25 \mathrm{~g}$ of L-arginine/day.

Different letters indicate significant difference $(\mathrm{p}<0.05)$ between values measured in different days within the same group.

Different numbers indicate significant difference $(\mathrm{p}<0.05)$ between values measured in different groups within the same day.

\section{Echocardiography Measurements}

The degree of pulmonary hypertension (PHT) was determined by echocardiography. Baseline measurements showed that the degree of PHT ranged from trace PHT (or trace tricuspid regurgitation) to severe PHT (pulomary artery pressure reached 100 mmHg). The results of PHT measured for the placebo and the other two groups showed no differences in the echocardiograph before or after L-arginine supplemntation. These results cannot be illustrated in tables since there is no specific measuring value.

Measurements of $\mathrm{O}_{2}$ Saturation $\%\left(\mathrm{O}_{2}\right.$ Sat. $\%)$ and Heart Rate

Changes in $\mathrm{O}_{2}$ saturation \% $\left(\mathrm{O}_{2}\right.$ Sat. \%) and heart rate as indicators for exercise tolerance for different groups at the beginning and the end of the study are shown in Table 5. The changes in $\mathrm{O}_{2}$ sat. \% and heart rate values show no significant differences among the study groups or days.

\section{Discussion}

In severe COPD, pulmonary hypertension (PHT) may develop as a consequence of hypoxia. The severity of PHT determines the degree of the patient's disability. Therefore, patients in severe situations are upset and irritable even at rest; and performance of any light activity may cause exhaustion, which is adversely affects the quality of life. However, introducing an agent that helps in preventing or at least alleviating hypoxia may reverse the bad consequences and improve the quality of life.

The results of amino acid analyses indicate that L-arginine supplementation in both groups increased the plasma level of arginine and ornithine significantly as compared with baseline values and placebo group, whereas citrulline remained constant during the study. Presumably, a substantial amount of L-arginine was converted to ornithine and urea through the arginineornithine pathway. 
Table 5. Changes in $\mathrm{O}_{2}$ saturation \% $\left(\mathrm{O}_{2}\right.$ Sat. \%) and heart rate as indicators for exercise tolerance for different groups at the beginning and the end of the study.

\begin{tabular}{|c|c|c|c|c|}
\hline Parameter & Days & $\begin{array}{c}\text { Group A } \\
(\text { Mean } \pm \text { SE) }\end{array}$ & $\begin{array}{c}\text { Group B }^{\#} \\
(\text { Mean } \pm \text { SE })\end{array}$ & $\begin{array}{l}\text { Group C } \\
(\text { Mean } \pm \text { SE) }\end{array}$ \\
\hline \multirow[t]{2}{*}{$\Delta \mathrm{O}_{2}$ Sat. $\%$} & 0 & $(-) 8.1 \pm 5.7^{\text {a } 1}$ & $(-) 7.5 \pm 3.4^{\text {a } 1}$ & (-) $10.7 \pm 9.8^{\text {a } 1}$ \\
\hline & 14 & $(-) 6.9 \pm 2.8^{\text {a } 1}$ & $(-) 5.3 \pm 2.9^{\text {a } 1}$ & $(-) 7.8 \pm 7.17^{\text {a } 1}$ \\
\hline \multirow{2}{*}{$\begin{array}{c}\Delta \text { Heart Rate } \\
\text { (beat/min.) }\end{array}$} & 0 & $(+) 21.9 \pm 13.9^{\text {a } 1}$ & $(+) 23.2 \pm 11.4^{\text {a } 1}$ & $(+) 19.3 \pm 7.3^{\text {a } 1}$ \\
\hline & 14 & $(+) 15.1 \pm 8.7^{\text {a } 1}$ & $(+) 15.8 \pm 9.9^{\text {a } 1}$ & $(+) 16.2 \pm 6.9^{\text {a } 1}$ \\
\hline
\end{tabular}

$\Delta$ Changes in parameters during the exercise tolerance test (from starting and at the end of the test period).

\# Group A is placebo, group B includes the patients who received $15 \mathrm{~g}$ of L-arginine/day, whereas group $\mathrm{C}$ represents patients who received $25 \mathrm{~g}$ of L-arginine/day.

Different letters indicate significant difference $(p<0.05)$ between values measured in different days within the same group.

Different numbers indicate significant difference $(p<0.05)$ between values measured in different groups within the same day.

(-) Indicates that the change is descending, while $(+)$ indicates that the change is ascending.

The increase in ornithine formation was more pronounced in the group which received $25 \mathrm{~g}$ of L-arginine/day, which means that ornithine formation is L-arginine dose-dependent. This may explain the mechanism of how the body is able to maintain the L-arginine level constant despite the continuous L-arginine supplementation at different doses (15 and $25 \mathrm{~g} /$ day). These results are in agreement with the study of Barbul et al. (1990), who measured the L-arginine and ornithine after oral supplementation with 17 and $25 \mathrm{~g}$ of Larginine hydrochloride for two weeks and the results indicated a significant increase in plasma arginine and ornithine levels throughout the study. It was reported in another study that patients supplemented with a lower dose (6 g/day) of L-arginine produced a significant increase in ornithine level and a constant level of citrulline before and after the supplementation (Ceremuzynski et al., 1997).

The results of urinary L-arginine, Lornithine and L-citrulline indicate that there was no changes in the renal excretion for those three amino acids in the groups supplemented with L-arginine. In other words, the elevation in plasma L-arginine and L-ornithine was tolerable without an evidence for spilling out of these two amino acids in urine. A study by Tangophao et al., (1999) demonstrated that oral supplementation with $6 \mathrm{~g}$ /day of L-arginine was not associated with renal clearance of Larginine, which coincides with the results of the present study.

The trend in ornithine elevation and consistency in citrulline levels, in spite of Larginine supplementation, are confirmed by the results of urea and NO. Urea was produced concomitantly with ornithine from L-arginine. Therefore, it can be concluded that an increase in ornithine production will be accompanied by an increase in urea formation (arginine-urea pathway), which the fact was observed in the present study.

Regarding the results of nitric oxide, which is produced from L-arginine by nitric oxide synthase (NOS), it is clear that NO production may not have been affected by Larginine supplementation and even a clear trend cannot be deduced. In other words, NO metabolites $\left(\mathrm{NO}_{2}\right.$ and $\left.\mathrm{NO}_{3}\right)$ which were determined in patients' urine do not reflect 
the effect of L-arginine supplementation; rather they may reflect the diet contribution.

Although radioactive isotopes were not used, it could be suggested that activation or induction of more NOS may not be achieved by arginine supplementation. This result was consistent with that of Blum et al., (2000) who examined the effect of oral L-arginine administration (9 g/day) to individuals with coronary artery disease. In this randomized, double-blinded crossover study, they assessed the flow-mediated brachial artery dilation before and after one month of therapy. They failed to find an effect of supplementing L-arginine on NO formation. Another study demonstrated that L-arginine supplementation (40 g/day) for 6 days did not alter the total daily urinary nitrate excretion nor the plasma concentration of nitrate (Beaumier et al., 1995).

Arterial blood gases $\left(\mathrm{P}_{\mathrm{a}} \mathrm{O}_{2}\right.$ and $\left.\mathrm{P}_{\mathrm{a}} \mathrm{CO}_{2}\right)$, degree of pulmonary hypertension (PHT), and exercise tolerance $\left(\mathrm{O}_{2}\right.$ sat \% during $6 \mathrm{MW}$ ) values were measured at the beginning and end of the study and no significant differences between groups during the study were found.

There was an improvement in $\mathrm{P}_{\mathrm{a}} \mathrm{O}_{2}$, especially in the group supplemented with $15 \mathrm{~g}$ of L-arginine/day as compared with the group which ingested $25 \mathrm{~g}$ /day and the placebo group; but this improvement was not statistically significant. The degree of PHT (measured by echocardiography) remained the same before and after Larginine supplementation, which indicates the absence of any clinically significant hemodynamic effect. Moncada et al., (1991) found that prolonged hypoxaemia may cause impairment in the production or release of NO (EDRF) from the endothelium; initially it was reversible with therapy, but became irreversible as hypoxaemia worsened and patients developed $\mathrm{CO}_{2}$ retention.

The different mechanisms by which Larginine affects the endothelial cells can partially explain controversies. Findings in the study of Boger et al. (1996) showed that L-arginine administration may stimulate NO production and induce vasorelaxation in coronary artery disease but may not exert the same action on patients with PHT. A study by Giaid and Saleh (1995) demonstrated that PHT is associated with diminished expression of eNOS. This may be attributed to irreversible changes in pulmonary artery structure, and so administration of Larginine late in the course of PHT did not reverse the homodynamic or structural changes that took place.

Finally, it seems that the absence of any response of improvement on exercise tolerance could be secondary to the chronic illness or the bad lung disease consequences or a combination of the two. The beneficial effects of L-arginine supplementation leading to improvements in exercise tolerance may be obtained in patients with heart diseases (Ceremuzynski et al., 1997, Fujita et al., 2000), not with pulmonary diseases.

\section{Conclusions}

From the results of the present study, it could be concluded that ornithine and urea formation was L-arginine dose-dependent. There is a significant increase in plasma arginine, ornithine and urea concentrations in both groups which received 15 and 25 gm of L-arginine/day. This increase in plasma ornithine and urea formation was higher in the group which was supplemented with 25 gm/day as compared with the placebo group. L-Arginine supplementation may not cause a detectable enhancement on citrulline and NO production. The results of plasma citrulline and urinary nitrate suggest that there was a consistency in plasma citrulline concentrations and no obvious changes in urinary NO in the three groups. There was inclination of improvement in the $\mathrm{P}_{\mathrm{a}} \mathrm{O}_{2}$ values in both groups which consumed Larginine; this improvement was more in the group which was supplemented with $15 \mathrm{gm}$ of L-arginine /day. Forced expiratory volume at one second $\left(\mathrm{FEV}_{1}\right)$ and the grade of pulmonary hypertension (PHT) values were not affected by L-arginine supplementation at either dose. Therefore, L-Arginine supplementation did not significantly improve the exercise tolerance 
under the conditions used in the present study.

\section{Acknowledgements}

We like to express our thanks and appreciation to Dr. Khaled Al-Asad (Jordan University Hospital, Jordan) for his valuable inputs in proposing and applying the study, and to Dr. Abdul Mone'm Shararah, Dr. Haytham Al-Khoshman, and Dr. Manaf Hejazi (King Hussein Medical Center, Amman), Dr. Ghannam Jarar (Islamic Hospital, Amman), and Dr. Hesham AlHourani (Al-Basheir Hospital) for their help, welcome and cooperation in applying the study in their clinics. Also, our deep thanks are extended to all the staff of Research and Development Department (R\&D), in United Pharmaceuticals Manufacture (UPM) in Jordan for their help in preparing L-arginine sachets and performing the analyses of amino acids. We are also very grateful to Dr. Fuad A. Abdulla for his reviewing and auditing of the paper.

\section{References}

Allegra, L. and F. Blasi. 1999. Mechanism and Management of COPD Exacerbation, Springer-Verlag, Italia, Sri.

Barbul, A., R. S. Fishel, S. Shimazu, H. L. Wasserkrug, N. N. Yushimura, R. C. Tao and G. Eron. 1985. Intravenous Hyperalimentation with High Arginine Levels Improves Wound Healing and Immune Function. Journal of Surgical Research 38: 328-334.

Bauerle, O., C. Chrusch and M. Younes. 1998. Mechanisms by which COPD Affects Exercise Tolerance, Am. J. Respir. Crit. Care Med. 157: 57-68.

Beaumier, L., L. Castillo, A. Ajimi and V. Young. 1995. Urea Cycle Intermediate Kinetics and Nitrite Excretion at Normal and Therapeutic Intakes of Arginine in
Humans, Am. J. Physiol. 269: E884E896.

Blum, A., L. Hathaway, R. Mincemoyer, W. Schenke, M. Kirby and G. Csako. 2000. Oral L-Arginine in Patients with Coronary Artery Disease on Medical Management, Circulation 101(18): 21602164.

Boger, R., S. Bode-Boger, A. Mugge, S. Kienie, R. Brandes and J. Frolich. 1996. Supplemental of Hypercholesterolaemic Rabbits with L-Arginine Reduces the Vascular Release of Superoxide Anions and Restores NO Production, Atherosclerosis 117: 273-284 (abstract).

Ceremuzynski, L., T. Chamiec and K. Herbaczynska-Ccdro. 1997. Effect of Supplemental or al L-Arginine on Exercise Capacity in Patients with Stable Angina Pectoris, J. Am. Coll. Cardiol. 80: 331-333.

Dinh-Xuan, A. T., T. W. Higenbottam, C. A. Clelland, J. Pepke-Zaba, G. Cremona, A. Y. Butt, S. R. Large, F. C. Wells and J. Wallwork. 1991. Impairment of Endothelium-Dependent PulmonaryArtery Relaxation in Chronic Obstructive Lung Disease. N. Engl. J. Med. 324(22): 1539-1547.

Eddahibi, S., S. Adnot, C., Carville, Y. Blouquit and B. Raffestin. 1992. LArginine Restores EndotheliumDependent Relaxation in Pulmonary Circulation of Chronically Hypoxic Rats. Am. J. Physiol. 263: L194-L200.

Fujita, H., H. Yamabe and M. Yokoyama. 2000. Effect of L-Arginine Administration on Myocardial Thallium201 Perfusion during Exercise in Patients with Angina Pectoris and Normal Coronary Angiograms, J. Nucl. Cardiol. 7(2): 97-102 (abstract). 
Giaid, A. and D. Saleh. 1995. Reduced Expression of Endothelial Nitric Oxide Synthase in the Lungs of Patients with Pulmonary Hypertension, N. Engl. J. Med. 333: 214-221.

Gold, M., B. Bush and L. Ignarro. 1990. Depletion of Arterial L-Arginine Causes Reversible Tolerance to EndothelialDependent Relaxation, Biochem. Biophys. Res. Commun. 164: 714-721.

Goldman, A., R. Tasker, S. Hawoth, P. Sigston and D. Macrae. 1996. Four Patterns of Response to Inhaled Nitric Oxide for Persistent Pulmonary Hypertension of the Newborn, Pediatrics 98: 706-713.

Heath, D. An Introduction to Experimental Design and Statistics for Biology, UCL Press.

Kinsella, J. and S. Abman. 1998. Controversies in the Use of Inhaled Nitric Oxide Therapy in the Newborn, Clin. Perinatol. 25: 203-217 (Abstract).

Loscalzo, J. 1995. Endothelial Dysfunction in Pulmonary Hypertension, N. Engl. J. Med. 327: 117-119.

Lowenstein, C., J. Dinerman and S. Snyder. 1994. Nitric Oxide: A Physiologic Messenger, Ann. Intern. Med. 120: 227237.

Mehta, S., D. Stewart and R. Levy. 1996. The Hypotensive Effect of L-Arginine is Associated with Increased Expired Nitric Oxide in Humans, Chest 109: 15501555.

Miller, V. 1983. Selective Production of Endothelium-Derived Nitric Oxide in Canine Femoral Veins, Am. J. Physiol. 261: H677-H682.

Mitani, Y., K. Maruyama and M. Sakurai. 1997. Prolonged Administration of LArginine Ameliorates Chronic
Pulmonary Hypertension and Pulmonary Vascular Remodeling in Rats, Circulation 96: 689-697.

Moncada, S. and A. Higgs. 1993. The LArginine-Nitric Oxide Pathway, N. Engl. J. Med. 329(27): 2002-2012.

Moncada, S., R. Palmer and E. Higgs. 1991. Nitric Oxide: Physiology, Pathophysiology, and Pharmacology, Pharmacol. Rev. 43: 109-124.

Palmer, R. M. J., D. S. Ashton and S. Mocada. 1988, Vascular Endothelial Cells Synthesize Nitric Oxide from LArginine. Nature 333: 664-666.

Pepke-Zaba, J., T. W. Higenbottam, A. T. Dinh-Xuan, D. Stone and J. Wallwork. 1991. Inhaled Nitric Oxide as a Cause of Selective Pulmonary Vasodilation in Pulmonary Hypertension. Lancet 338: 1173-1174.

Roberts, J., D. Poaner, P. Lang and W. Zapol. 1992. Inhaled Nitric Oxide in Persistent Pulmonary Hypertension of the New Born, Lancet 340: 818-819.

Rounds, S. and N. Hills. 1984. Pulmonary Hypertension Diseases, Chest 85: 397405.

Shiral, M., A. Shimouchi, A. Kawaguchi and K. Sunagawa. 1996. Inhaled Nitric Oxide: Diameter Response Patterns in Feline Small Pulmonary Arteries and Veins, Am. J. Physiol. 270: H974-980.

Siafakas, N. M., P. Vermeire, N. B. Pride, P. Paoletti, J. Gibson, P. Howard, J. C. Yernault, M. Decramer, T. Higenbottam, D. S. Postma and J. Rees. 1995. Optimal Assessment and Management of Chronic Obstructive Pulmonary Disease (COPD); A Consensus Statement of the European Respiratory Society. Eur. Respir. J. 8: 1398-1420. 
Tangphao, O., M. Grossmann, S. Chalon, B. Hoffman and T. Blaschke. 1999. Pharmacokinetics of Intravenous and Oral L- Arginine in Normal Volunteers, Br. J. Clin. Pharmacol. 47:261-266.

Teerlink, T., P. van Leeuwen and A. Houdijk. 1994. Plasma Amino Acids Determined by Liquid Chromatography within 17 Minutes, Clin. Chem. 40(2): 245-249.
Wascher, T. C., K. Posch, S. Wallner, A. Hermetter, G. M. Kostner and W. F. Graier. 1997. Vascular Effects of LArginine: Anything beyond a Substrate for the NO-Synthase. Biochem. Biophys. Res. Commun. 173: 940-948.

Winshaw, H. C. and J. F. Murray. 1980, Diseases of the Chest, $4^{\text {th }}$. Edition. W. B. Saunders Company, USA, PA. 